\title{
単位光束法の照明器具高さによる補正とその適用範囲 CORRECTION OF FLUX-UNIT METHOD BY LUMINAIRE HEIGHT AND THE APPLICABLE RANGE
}

\author{
松下 進*, 三木保弘**, 上谷芳昭*** \\ Susumu MATSUSHITA, Yasuhiro MIKI and Yoshiaki UETANI
}

\begin{abstract}
"Flux-unit method" that we proposed previously is a simple lighting design method applicable to both non-integrated luminaires and integrated luminaires for residential architects. In the method, the room's total luminaire luminous flux is calculated, and then, according to the zoning of residential behaviors in the room, luminaire luminous flux is distributed within the limits of the total luminaire luminous flux considering total energy consumption. Since this method in our previous studies assumes the use of luminaires on the ceiling, it cannot be used when luminaire height is less than ceiling height. Therefore, we derived the correction formula of "Flux-unit method" by luminaire height using the relationship between square of luminaire height and "flux-unit", and we also executed a trial design with this correction formula. Consequently, it was shown that "Flux-unit method" is applicable to luminaires of various height under the limited applicable range used in this study.
\end{abstract}

Keywords : Flux-unit method, Lighting design, Residential lighting, Luminaire height, Ceiling height, Luminaire luminous flux 単位光束法, 照明設計, 住宅照明, 照明器具高さ, 天井高さ, 器具光束

\section{1.はじめに}

近年、住宅照明においては光環境および省エネルギー性の向上を実 現する多灯分散照明方式 ${ }^{12)}$ 瞙及しつつあり、さらに LED 照明が 主流になってきている。そこで多灯分散照明方式および LED 照明に 対応し、住宅建築設計者が簡易に照明設計を行えることを目的とした 単位光束法 ${ }^{34) 5}$ ) が筆者らにより提案されている。

この設計法は、部屋の大きさや内装反射率といった設計条件ごとに、 基準照度である床面平均照度 50 ルクスを得るのに必要な照明器具の 器具光束注1) である単位光束を一覧表にした単位光束表を、予めデー タベースとして用意しておく注2) ことで、住宅建築設計者が照度計算 ソフトによる照度計算等を行わずに、室内全体の床面平均照度やゾー ン注3) の床面平均照度を得るためのランプ一体型照明器具およびラン プ分離型照明器具の器具光束の量を手計算レベルで検討できる。また、 照明器具の効率である固有エネルギー消費効率注 4) を用いて器具光束 を消費電力に換算することで、室内全体やゾーンの消費電力を簡易に 検討できる。

単位光束法においては、視作業を伴う生活行為を行うゾーンを明視 照明ゾーンとして計画し、通常水平面照度を高く設定する。但し、明 視照明ゾーンでは天井照明器具の使用を想定しており、天井高さも一 定という前提条件がある。これは住宅照明でよく使われるシーリング
ライトやダウンライトのように天井と照明器具高さがほぼ等しい場合 は問題がないが、ペンダントライトのように照明器具高さが天井高さ と異なる場合は使用できない。

単位光束法を照明器具高さが天井高さと異なる場合に対応できる形 とすることができれば、天井照明器具以外の照明器具が使用でき、単 位光束法の適用範囲が拡大寸る。その際、照明器具高さが異なる場合 の複数の単位光束表を作成するという方法も考えられるが、照明器具 高さを細かく変化させると膨大な単位光束表の数となる恐れがあり、 現実的でない。代わりに、従来の単位光束表における単位光束を照明 器具高さにより補正する形の方が、設計者の利便性を重視するという 単位光束法の本旨に沿う。そこでその補正式を導出し、設計例の試行 を行うことにより、実務における簡便な照明設計法として照明器具の 設置高さの適用範囲を拡大寸ることを本研究の目的とする。

\section{2. 単位光束法の設計手順および単位光束の算出手順}

照明器具高さによる補正式の導出の前に、従来の単位光束法の設計 手順および単位光束の算出手順を示す。

\section{1 単位光束法の設計手順}

まず、従来の単位光束法の設計手順を示し、本研究の照明器具高さ による補正をどの段階で行うかを示す。

\footnotetext{
* 松下進建築·照明設計室 代表·工修 京都大学大学院 博士課程

** 国土交通省国土技術政策総合研究所住宅研究部 建築環境研究室 室長・博士 (工学)

*** 京都大学工学研究科建築学専攻 准教授.工博 (2016 年 7 月逝去)

President, Susumu Matsushita Architecture \& Lighting Design Labo., M. Eng.

Grad. Student, Dept. of Architecture and Architectural Engineering, Kyoto University

Head, Building Environment Division, Housing Department, National Institute for Land and

Infrastructure Management, MLIT, Dr. Eng.

Assoc. Prof., Dept. of Architecture and Architectural Engineering, Kyoto University, Dr. Eng.
} 
(1) 天井中央に拡散配光器具を設置すると仮定し、室内全体の最大光 束 $F_{\max }$ を拡散配光器具の単位光束表 (表 1 ) を用いて式 (1)より算出 する。設計照度 $E_{\text {room }}$ は 100 ルクスを標準とする。基本照度 $E_{b}$ は、 単位光束表において基本となる床面平均照度 50 ルクスである。

$F_{\max }=F_{\text {unit_lumi }}\left(E_{\text {room }} / E_{b}\right) \quad \cdots$ (1)

$F_{\max }$ : 室内全体の最大光束 $(\mathrm{lm}) 、 F_{\text {unit_lumi }}$ : 単位光束 $(\mathrm{lm}) 、 E_{\text {room }}$ : 室内全体の設計照度 $(\mathrm{lx}) 、 E_{b}$ : 基本照度 $(\mathrm{lx})$

(2) 室内全体の最大消費電力 $W_{\max }$ を式 (2) より算出する。室内に標準 的な効率の照明器具を設置した場合を基準として, その消費電力を超 えないように設計を行うためである。式(2)における照明器具の固有 エネルギー消費効率 $L_{e r}$ は、標準で $55(\mathrm{~lm} / \mathrm{W})$ を想定している注5)。

$$
W_{\max }=F_{\max } / L_{e r} \quad \cdots(2)
$$

$W_{\max }$ : 室内全体の最大消費電力 $(\mathrm{W}) 、 L_{e r}$ : 照明器具の固有エネル ギー消費効率 $(\mathrm{lm} / \mathrm{W})$

(3) 視作業を伴い明るさを必要とする部分である明視照明ゾーンにお ける明視照明用部分光束 $F_{\text {task }}$ を式 (3) より算出する。その際、表 1 に おける採用予定の照明器具に近い配光の単位光束表を用いて、対象ゾ ーンの面積から単位光束を選択する。水平面照度を得るために直接照 明形 ${ }^{6}$ の配光器具を用いるが、一般的に比較的集光性の高い中照配光 器具は狭い範囲で用い、拡散性の高い拡散配光器具は広い範囲で用い、 中間的な光の広がりを持つ広照配光器具は中照配光器具と拡散配光器 具で用いる範囲の中間的な範囲で用いる。設計照度 $E_{z o n e}$ は、生活行 為から JIS 照明基準総則 ${ }^{7}$ を参照して決定する。

$$
F_{\text {task }}=F_{\text {unit_lumi }}\left(E_{\text {zone }} / E_{b}\right) \quad \cdots \text { (3) }
$$

$F_{\text {task }}$ : 明視照明用部分光束 $(1 \mathrm{~m}) 、 E_{\text {zone }}$ : 明視照明ゾーンの設計照 度 $(\mathrm{lx})$

(4) 明視照明用部分消費電力 $W_{\text {task }}$ を式 (4) より算出する。照明器具の 選択時に器具光束と併せて照明器具の消費電力を考慮するための目安 であり、消費電力がこの段階で多少超過しても問題ない。

$$
\begin{aligned}
& W_{\text {task }}=F_{\text {task }} / L_{e r} \quad \cdots \cdot(4) \\
& W_{\text {task }} \text { : 明視照明用部分消費電力 }(\mathrm{W})
\end{aligned}
$$

(5) 雰囲気を作り、明るさを必要としない部分である雰囲気照明ゾー ンにおける雰囲気照明用部分光束 $F_{\text {ambient }}$ を式 (5) より算出する。雾囲 気照明器具は床面照度の確保を優先しないため、配光は任意とする。

$$
F_{\text {ambient }}=F_{\text {max }}-F_{\text {task }} \quad \cdots \text { (5) }
$$

$F_{\text {ambient }}$ : 雰囲気照明用部分光束 $(1 \mathrm{~m})$

(6) 雰囲気照明用部分消費電力 $W_{\text {ambient }}$ を式(6)より算出する。(4)と同 様に、照明器具の選択時に器具光束と併せて照明器具の消費電力を考 慮するための目安であり、消費電力がこの段階で多少超過しても問題 ない。

$$
W_{\text {ambient }}=W_{\max }-W_{\text {task }} \quad \cdots(6)
$$

$W_{\text {ambient }}$ : 雰囲気照明用部分消費電力 $(\mathrm{W})$

(7) 各ゾーンの部分光束と部分消費電力を参照し、部分光束が照明器 具の器具光束と灯数の積に近くなるように照明器具を選定し、数量を 決定する。

(8) 選定した全ての照明器具の合計消費電力が、室内全体の最大消費 電力以内であることを確認する。

\begin{tabular}{|c|c|c|c|c|c|c|c|}
\hline \multicolumn{2}{|r|}{ 面積(畳) 注 1) } & 2 & 4.5 & 6 & 8 & 10 & 12.5 \\
\hline 拡 & $\begin{array}{l}\text { 内装反射率 (\%) } \\
\text { 天井 } 70 \text { 壁 } 30 \text { 床 } 10\end{array}$ & 1350 & 1700 & 1950 & 2200 & 2500 & 2850 \\
\hline $\begin{array}{l}\text { 散 } \\
\text { 配 }\end{array}$ & $\begin{array}{l}\text { 内装反射率 }(\%) \\
\text { 天井 } 70 \text { 壁 } 50 \text { 床 } 10\end{array}$ & 1100 & 1450 & 1700 & 1950 & 2250 & 2600 \\
\hline 光 & $\begin{array}{l}\text { 内装反射率 (\%) } \\
\text { 天井 } 70 \text { 壁 } 70 \text { 床 } 10 \\
\end{array}$ & 850 & 1250 & 1450 & 1700 & 2000 & 2350 \\
\hline
\end{tabular}

ここまでが従来の単位光束法の設計手順であるが、本研究における 照明器具高さによる補正は、明視照明ゾーンの照明器具を対象とする ため、設計手順(3)における明視照明用部分光束算出時において行う。

\begin{tabular}{|c|c|c|c|c|c|c|c|}
\hline \multicolumn{2}{|r|}{ 面積 (畳) 注 2) } & 1 & 2 & 4.5 & 6 & 8 & 10 \\
\hline 広 & $\begin{array}{l}\text { 内装反射率 (\%) } \\
\text { 天井 } 70 \text { 壁 } 30 \text { 床 } 10\end{array}$ & 750 & 850 & 1100 & 1300 & 1500 & 1700 \\
\hline $\begin{array}{l}\text { 照 } \\
\text { 配 }\end{array}$ & $\begin{array}{l}\text { 内装反射率 }(\%) \\
\text { 天井 } 70 \text { 壁 } 50 \text { 床 } 10\end{array}$ & 650 & 700 & 1000 & 1150 & 1400 & 1600 \\
\hline 光 & $\begin{array}{l}\text { 内装反射率 }(\%) \\
\text { 天井 } 70 \text { 壁 } 70 \text { 床 } 10\end{array}$ & 500 & 600 & 900 & 1050 & 1250 & 1500 \\
\hline
\end{tabular}

\section{表 1 天井照明器具における単位光束表}

[拡散配光器具における単位光束 $(\mathrm{lm})$ ]

\begin{tabular}{|c|c|c|c|c|c|c|c|}
\hline \multicolumn{2}{|r|}{ 面積(畳) 注 3) } & 0.5 & 1 & 2 & 4.5 & 6 & 8 \\
\hline 中 & $\begin{array}{l}\text { 内装反射率 (\%) } \\
\text { 天井 } 70 \text { 壁 } 30 \text { 床 } 10\end{array}$ & 300 & 360 & 440 & 700 & 870 & 1070 \\
\hline $\begin{array}{l}\text { 照 } \\
\text { 配 }\end{array}$ & $\begin{array}{l}\text { 内装反射率 (\%) } \\
\text { 天年 } 70 \text { 壁 } 50 \text { 床 } 10\end{array}$ & 270 & 330 & 410 & 670 & 840 & 1040 \\
\hline 光 & $\begin{array}{l}\text { 内装反射率 (\%) } \\
\text { 天井 } 70 \text { 壁 } 70 \text { 床 } 10\end{array}$ & 230 & 290 & 370 & 640 & 810 & 1020 \\
\hline
\end{tabular}

表注 1： 2 畳から 12.5 畳の範囲に適用寸る

[広照配光器具における単位光束 $(\mathrm{lm})$ ]

表注 2: 1 畳から 10 盢の範囲に適用寸る

[中照配光器具における単位光束 $(\mathrm{lm})$ ]

表注 3：0.5 畳から 8 畳の範囲に適用する

\section{2 . 2 単位光束の算出手順}

次に、単位光束の算出手順を示す。但し、単位光束表は単位光束法 の使用時には予め用意されており、設計者が算出する必要はない。

(1) 照明空間の大きさを設定する。

(2) 天井、壁、床の反射率を設定する。

(3) 対象照明器具の配光を設定する。

(4) 照明器具を天井中央に配置する。

(5) 照明計算を行い、床面平均照度 $E_{a V}(\mathrm{~lx})$ を計算させる。

Radiance 注6) のパラメータ : -ab 3, -aa 0.15, -ar 128, -ad 512, -as 256 注7) (6) 基準照度 $50(\mathrm{~lx})$ と $E_{a v}(\mathrm{~lx})$ の比に対象照明器具の器具光束 $F_{-}$lumi $(\mathrm{lm})$ を乗じて、単位光束 $F_{\text {unit_lumi }}(\mathrm{lm})$ を式 $(7)$ より算出する。

$F_{\text {unit_lumi }}=F_{-}$lumi $\left(50 / E_{\text {av }}\right) \quad \cdots(7)$

$F_{-l u m i}$ : 対象照明器具の器具光束 $(\mathrm{lm}) 、 E_{a v}$ : 床面平均照度 $(\mathrm{lx})$

\begin{tabular}{|c|c|c|}
\hline \multirow{7}{*}{$\begin{array}{l}\text { 建 } \\
\text { 築 } \\
\text { 条 } \\
\text { 件 }\end{array}$} & 天井高さ (m) & 2.4 に固定 \\
\hline & 天井面反射率（\%) & 70 に固定 \\
\hline & 壁面反射率（\%) & $70 、 50 、 30$ の三種類 \\
\hline & 床面反射率（\%) & 10 に固定 ${ }^{\text {注 1) }}$ \\
\hline & 部屋の床面積注 2) (畳) & 拡散配光時：2、4.5、6、8、10、12.5 \\
\hline & & 広照配光時：1、2、4.5、6、8、10 \\
\hline & & 中照配光時： $0.5 、 1 、 2 、 4.5 、 6 、 8$ \\
\hline \multirow{7}{*}{$\begin{array}{l}\text { 照 } \\
\text { 明 } \\
\text { 条 } \\
\text { 件 }\end{array}$} & 照明器具の平面位置 & 天井中央に一灯 \\
\hline & 照明器具高さ（m） & 2.4 に固定 \\
\hline & 照明器具の配光 & 集光性の低い直接照明形配光 \\
\hline & 照明器具の光束 & 器具光束（ランプ光束ではない） \\
\hline & 被照面 & 床面に固定 \\
\hline & 保守率 & 0.7 \\
\hline & 基本照度（lx） & 50 \\
\hline
\end{tabular}

表 1 の単位光束算出における建築および照明の前提条件は表 2 、照 明器具は表 3 および図 1 の通りである。既存の単位光束表は表 1 のみ であるが、新しい照明器具の単位光束表を作成する際も、表 2 を前提 条件とする。

\section{表 2 単位光束算出における建築および照明の前提条件}

表注 1: 10\%より高い反射率も考えられるが、床面に置かれる家具などが特定できないため 安全側である低い反射率を採用している

表注 2 : 部屋の平面形状は正方形あるいは正方形に近い長方形 
表 3 単位光束算出用照明器具

\begin{tabular}{|l|l|r|}
\hline \multicolumn{1}{|c|}{ 配光の型 } & \multicolumn{1}{|c|}{ 明器具の種類 } & 4500 \\
\hline 拡散 & 47WLED シーリングライト & 450 \\
\hline 広照 & $8.8 W$ 電球形 LED ランプダウンライト & 370 \\
\hline 中照 & $6.9 W$ LED ランプ一体型ダウンライト & \\
\hline
\end{tabular}
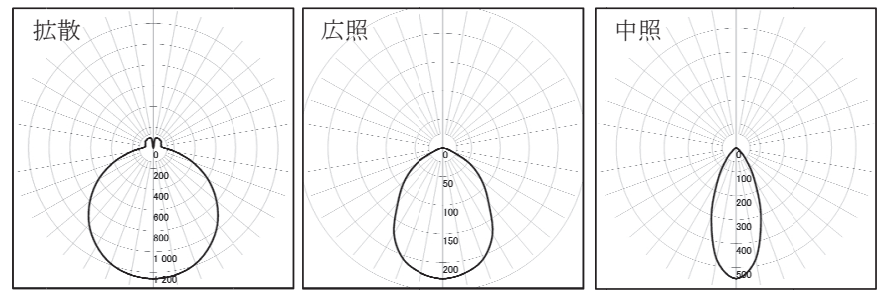

図 1 単位光束算出用照明器具の配光曲線図

\section{3. 照明器具高さによる補正式の導出}

\section{1 照明器具高さによる補正式導出の検討手順}

照明器具高さから単位光束を予測する補正式は、複数の照明器具高 さの単位光束を算出した後、照明器具高さとその単位光束との相関を 用いて導く。その際、住宅ではシーリングライトなどの天井照明のよ うに照明器具と天井高さが等しい場合の単位光束が多く使われるため、 その単位光束を照明器具高さに応じて補正する方法を検討する。但し、 照明器具高さが天井高さより大きいことは一般的に考えられないため、 照明器具高さが天井高さより小さい場合のみを検討する。

また、従来の単位光束法で想定している天井照明器具と、ペンダン トライトなどの照明器具高さが天井高さより小さい照明器具では、配 光が異なることが考えられる。天井照明器具は下半球光束 ${ }^{8)}$ 主体の直 接照明形の配光であるが、ペンダントライトなどは直接照明形だけで なく、下半球光束と上半球光束 ${ }^{8}{ }^{8}$ が同程度、あるいは下半球光束より 上半球光束が多く出る配光も多い。しかし本研究における照明器具高 さによる補正は、明視照明ゾーンで用いられる照明器具を対象として おり、本来、明視照明ゾーンにおいて使用される照明器具は、机上面 や床面の水平面照度を効率的に得る目的で設置されるため直接照明形 の配光を持つ照明器具が用いられる。そのため単位光束法では、照明 器具高さが天井高さと異なる照明器具においても直接照明形のタイプ を対象とし、直接照明形以外のタイプは、明視照明用照明器具でなく、 雾囲気照明用照明器具として扱うこととする。補正式検討の流れおよ び照明器具の設置位置 (図 2 ) を以下に示す。

(1) 照明器具高さ $H$ に応じた単位光束 $U F(H) の$ 算出

(2) 照明器具高さ $H$ と算出した単位光束 $U F(H)$ との相関の検討

(3) 照明器具高さ $2.4 \mathrm{~m}$ の単位光束 $U F(2.4)$ を用いた補正式の導出 $U F(H)=f(U F(2.4), H)$

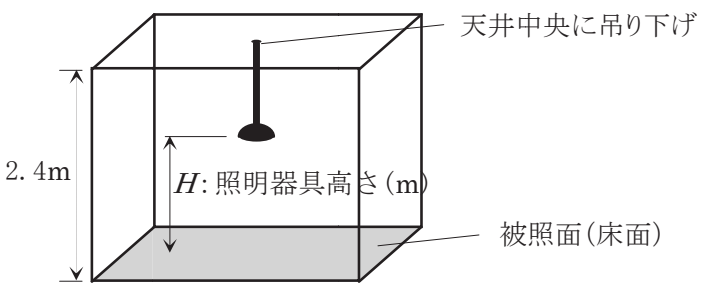

図 2 照明器具の設置位置

\section{2 照明器具高さに応じた単位光束の算出}

照明器具高さに応じて、基準照度である床面平均照度 50 ルクスを 得るための単位光束を算出する。

\section{2.1 単位光束算出の条件}

建築および照明の前提条件は照明器具高さの項目以外は表 2 、表 3 および図 1 の通りであり、照度計算ソフトは Radiance 注6) を用いた。

\section{2 .2 単位光束の算出}

単位光束算出の条件に従って、各照明器具高さにおける単位光束を 算出した。照明器具高さの種類は無数に考えられるが、照明器具高さ と天井高さが等しい場合の単位光束を用いた補正を考えることから、 代表值として天井高さから算出しやすい高さとした。単位光束算出時 のパラメータは表 2 のパラメータに照明器具高さを加えた表 4 の通り であり、条件は全部で 324 通りとなる。算出した単位光束表の例を表 5 に示す。

表 4 単位光束算出における高さを考慮したパラメータ

\begin{tabular}{|l|c|l|}
\hline \multicolumn{1}{|c|}{ パラメータ } & 数 & \multicolumn{1}{|c|}{ 要素 } \\
\hline 照明器具高さ $(\mathrm{m})$ & 6 & $0.6 、 0.8 、 1.2 、 1.6 、 1.8 、 2.4$ \\
\hline 照明器具の配光 & 3 & 拡散、広照、中照 \\
\hline 部屋の床面積泩) (盢) & 6 & 拡散配光時：2、4.5、6、8、10、12.5 \\
\cline { 3 - 4 } & & 広照配光時：1、2、4.5、6、8、10 \\
\cline { 3 - 4 } & & 中照配光時：0.5、1、2、4.5、6、8 \\
\hline 部屋の壁面反射率 $(\%)$ & 3 & $30 、 50 、 70$ \\
\hline
\end{tabular}

表注 : 床面積の適用畳数は配光によって異なるが、いずれも 6 種類

\section{表 5 照明器具高さに応じた単位光束表の例}

[照明器具高さ $0.6 \mathrm{~m}$ の場合の単位光束 $(1 \mathrm{~m})$ : 中照配光の場合］

\begin{tabular}{|c|c|c|c|c|c|c|c|}
\hline \multicolumn{2}{|c|}{ 面積(畳) } & 0.5 & 1 & 2 & 4.5 & 6 & 8 \\
\hline 中 & $\begin{array}{l}\text { 内装反射率 }(\%) \\
\text { 天井 } 70 \text { 壁 } 30 \text { 床 } 10\end{array}$ & 76 & 137 & 248 & 531 & 697 & 916 \\
\hline 照 & $\begin{array}{l}\text { 内装反射率 }(\%) \\
\text { 天井 } 70 \text { 壁 } 50 \text { 床 } 10\end{array}$ & 74 & 135 & 247 & 529 & 695 & 914 \\
\hline 光 & $\begin{array}{l}\text { 内装反射率 }(\%) \\
\text { 天井 } 70 \text { 壁 } 70 \text { 床 } 10\end{array}$ & 71 & 132 & 244 & 527 & 693 & 912 \\
\hline
\end{tabular}

\section{3 照明器具高さと算出した単位光束との相関の検討}

\subsection{1 近似式を用いた相関の検討}

前項で求めた 324 通りの単位光束に基づき、各条件における照明器 具高さ $H$ と単位光束 $U F(H)$ の関係を配光・壁面反射率の組み合わせ 9 通りでグラフ化し、部屋の床面積の違い 6 通りそれぞれについて、 $H$ を変数として $U F(H)$ を近似寸る 2 次式を得た（図 3 ）。この近似 式を用いれば、照明器具高さから直接単位光束が得られるが、単位光 束法では設計者が手計算で簡易に室内光束が算出できることを特長と しており、各条件において異なった近似式を用いると、全部で 54 通 りの 2 次式が必要となることから、煩雑である。

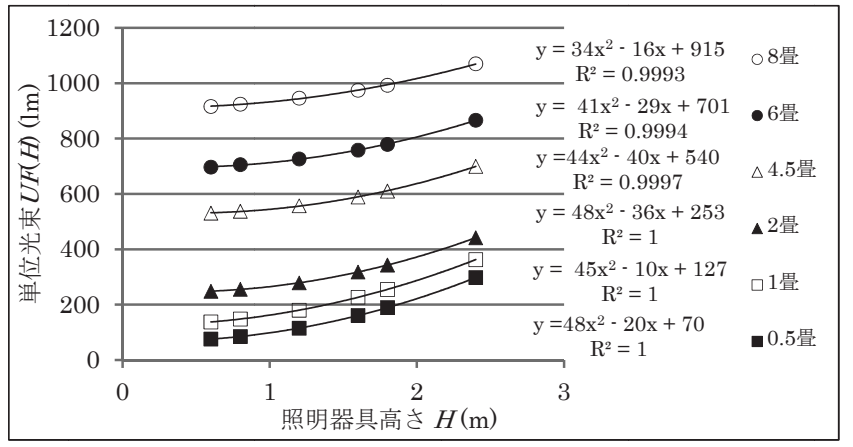

図 3 照明器具高さ $H$ と單位光束 $U F(H)$ の関係 [中照配光、壁面反射 率 30\%の場合] 


\section{3.2 近似式の簡易化の検討}

ここで照度計算の基本である逆 2 乗則を顧みると、被照面の直射照 度が一定の場合、照明器具の光度值は照明器具と照射面の距離の 2 乗 に比例する。また、器具光束は光度值の積分で算出できる。さらに、 照明器具の高さが変わっても、室内の間接照度は室内の表面積と反射 率により決まるため、建築条件が等しい場合は概ね一定となる注 8)。 これらから、単位光束は直接照度に関わる照明器具高さの 2 乗を変数 と寸る変数項と間接照度に関わる定数項の和のみで近似できる可能性 があり、これは前項の $H$ の 2 次式における 1 次項を減らせる可能性 を示している。そこで、その簡易化を検討寸ることとした。

各条件における照明器具高さの 2 乗 $H^{2}$ と単位光束 $U F(H)$ の関係 を前項と同様にグラフ化し、Hの 1 次項のない $U F(H)$ の近似式を得

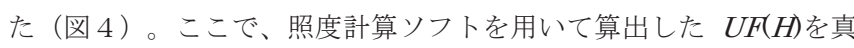
值とし、Hの 1 次項のある前項の近似式を用いて $U F(H)$ を算出した 場合の誤差と、Hの 1 次項のない本項の近似式を用いて $U F(H)$ を算 出した場合の誤差を比較した。 $H$ の 1 次項のある近似式による誤差は $\pm 1 \%$ 以内であり、Hの 1 次項のない近似式による誤差は中照配光器 具の数点において $2 \%$ を超えるものの、概衫 $\pm 2 \%$ 以内となった（図 5 ）。これより、本項で導いた $H$ の 1 次項のない、 $H^{2}$ の変数項と定 数項のみから成る近似式は、やや精度が低くなるが簡便な式として適 用範囲にある。

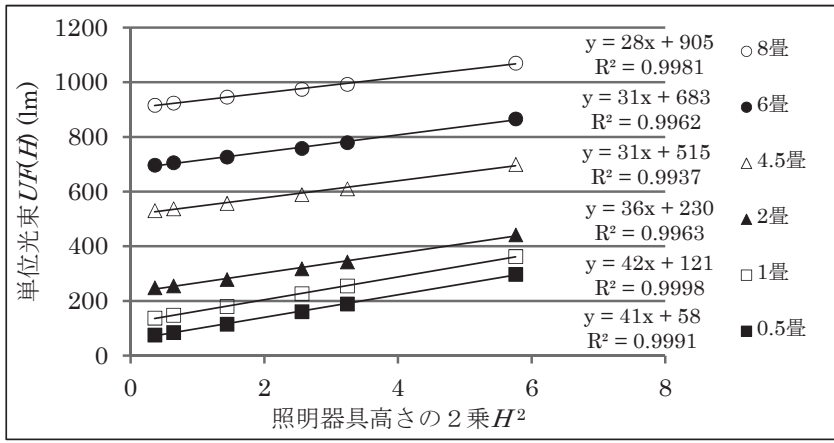

図 4 照明器具高さの 2 乗 $H^{2}$ と単位光束 $U F(H)$ の関係 [中照配光、壁 面反射率 $30 \%$ の場合]

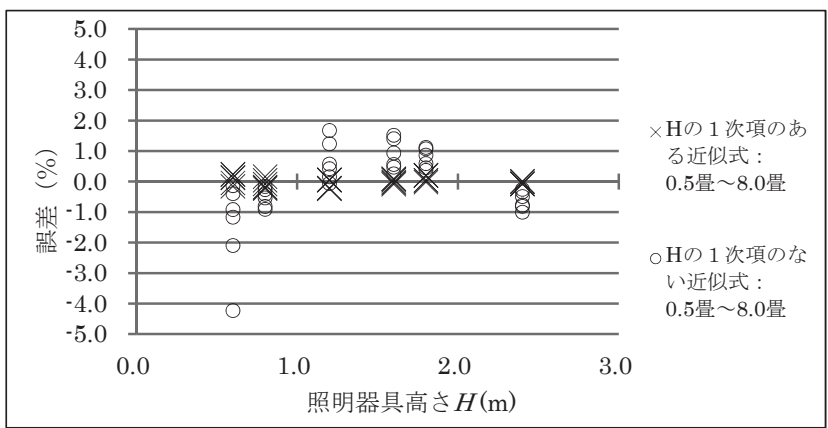

図 $5 H$ の 1 次項のある近似式と $H$ の 1 次項のない近似式の誤差 [中 照配光、壁面反射率 30\%の場合]

\section{4 照明器具高さ $2.4 \mathrm{~m}$ の単位光束を用いた補正式の導出}

\section{4.1 近似式の傾きを一つの定数とする更なる簡易化の検討}

図 4 において、近似式の傾きは部屋の 6 通りの畳数ごとにあまり変 わらない。これは、3.3.2 項の $H^{2}$ の変数項と定数項のみから成る近 似式による補正は、床面積に関わらず、近似式の傾きを一つの定数と
することにより更に簡易化できる可能性を示している。そこで、傾き を一つの定数で代表する補正式を検討する。

但し、照明器具高さ $2.4 \mathrm{~m}$ の場合の単位光束 $U F(2.4)$ をもとに照明 器具高さが $2.4 \mathrm{~m}$ より小さい場合の $U F(H)$ を算出することを想定して いるため、 $U F(2.4)$ と、その光束を照明器具高さ $H$ により補正する光 束（補正光束 $C F(H)$ ) を用いた補正とした。 $U F(H)$ は $U F(2.4)$ より小 さいため、補正式は $U F(2.4)$ から $C F(H)$ を差し引く形となる(式 (8))。

$U F(H)=U F(2.4)-C F(H) \quad \cdots(8)$

$U F(H)$ ：照明器具高さ $H$ における単位光束 $(1 \mathrm{~m}) 、$

$H$ : 照明器具高さ $(\mathrm{m})$ 、

$U F(2.4)$ : 照明器具高さ $2.4 \mathrm{~m}$ における単位光束 $(\mathrm{lm})$ 、

$C F(H)$ : 照明器具高さ $H$ による補正光束 $(\mathrm{lm})$

式(8)において、 $U F(H)$ は 3.3.2 項の $H^{2}$ の変数項と定数項のみから 成る近似式で近似でき、UF(2.4)は $H$ が $2.4 \mathrm{~m}$ の場合であるから、 $U F(2.4)$ と $U F(H)$ の差である $C F(H)$ は定数項が相殺され、 $2.4^{2}$ と $H^{2}$ の差を変数とする比例の式で近似できると考えられる。図 6 は、図 4 の床面積 4.5 畳の場合における上記の関係をグラフ上で示したもので ある。そこで、 $2.4^{2}$ と $H^{2}$ の差と、補正光束 $C F(H)$ の関係をグラフ化 寸ると、両者はほぼ比例関係にあることが確認できた（図 7 ）。

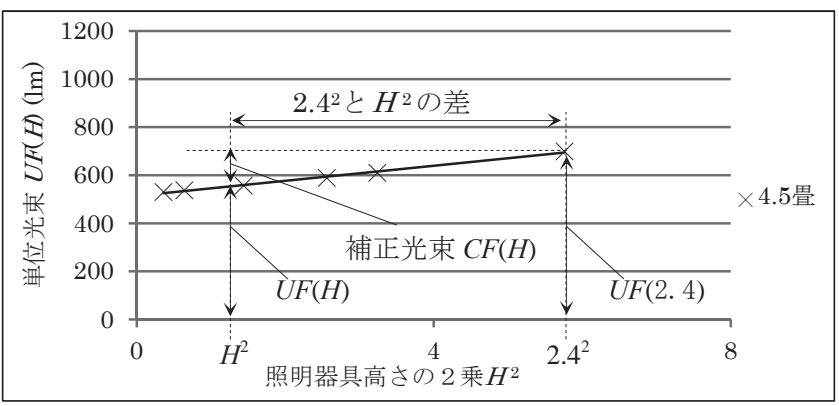

図 6 照明器具高さの 2 乗 $H^{2}$ 之補正光束 $C F(H)$ との関係［中照配光、 壁面反射率 $30 \%$ 、床面積 4.5 畳の場合]

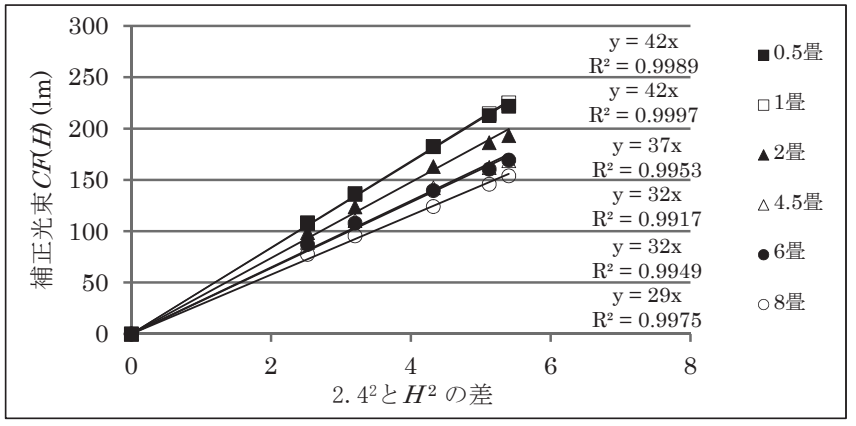

図 $72.4^{2}$ と $H^{2}$ の差と補正光束 $C F(H)$ の関係 [中照配光、壁面反射率 $30 \%$ の場合]

ここで図 7 は図 4 より導かれており、図 4 と同様に部屋の䪶数ごと の近似式の傾きの違いは小さい。そこで、まず近似式の傾きを一覽に した表 6 から、近似式の傾きの標準偏差と変動係数を算出した (表 7 )。 その結果、拡散配光器具および広照配光器具は変動係数が最大でも $6 \%$ 程度であり、散らばりは小さい。それらと比較して中照配光器具 の散らばりは大きく、変動係数が $10 \%$ 以上となっている。これらか ら、中照配光器具の誤差がやや大きくなる恐れはあるが、全体的に近 似式の傾きの散らばりは小さいため、壁面反射率が等しい場合は、床 
面積に関わらず、傾きを一つの定数で代表する補正式により補正でき る可能性が高い。そこで、部屋の畳数ごとの近似式の傾きが一定と仮 定して、補正式の検討を行った。

\section{表 6 近似式の傾き}

[拡散配光器具]

\begin{tabular}{|c|c|c|c|c|c|c|c|}
\hline \multirow{2}{*}{$\begin{array}{l}\text { 壁面反射 } \\
\text { 率 }(\%)\end{array}$} & \multicolumn{6}{|c|}{ 畳数 (畳) } & \multirow[b]{2}{*}{ 平均 } \\
\hline & 2 & 4.5 & 6 & 8 & 10 & 12.5 & \\
\hline 30 & 183 & 189 & 194 & 196 & 201 & 203 & 194 \\
\hline 50 & 138 & 145 & 150 & 153 & 158 & 160 & 151 \\
\hline 70 & 100 & 105 & 110 & 112 & 116 & 119 & 110 \\
\hline
\end{tabular}

[広照配光器具]

\begin{tabular}{|c|c|c|c|c|c|c|c|}
\hline \multirow{2}{*}{$\begin{array}{l}\text { 壁面 反射 } \\
\text { 率 }(\%)\end{array}$} & \multicolumn{6}{|c|}{ 畳数 (盢) } & \multirow[b]{2}{*}{ 平均 } \\
\hline & 1 & 2 & 4.5 & 6 & 8 & 1 & \\
\hline 30 & 112 & 105 & 104 & 106 & 104 & 10 & 106 \\
\hline 50 & 91 & 83 & 83 & 85 & 84 & 8 & 85 \\
\hline 70 & 70 & 63 & 63 & 65 & 64 & 6 & 65 \\
\hline
\end{tabular}

[中照配光器具]

\begin{tabular}{|c|c|c|c|c|c|c|c|}
\hline \multirow{2}{*}{$\begin{array}{l}\text { 壁面反射 } \\
\text { 率 }(\%)\end{array}$} & \multicolumn{6}{|c|}{ 畳数(畳) } & \multirow[b]{2}{*}{ 平均 } \\
\hline & 0.5 & 1 & 2 & 4.5 & 6 & 8 & \\
\hline 30 & 42 & 42 & 37 & 32 & 32 & 29 & 36 \\
\hline 50 & 36 & 36 & 31 & 27 & 27 & 24 & 30 \\
\hline 70 & 30 & 30 & 25 & 22 & 22 & 19 & 25 \\
\hline
\end{tabular}

\section{表 7 近似式の傾きの標準偏差と変動係数}

\begin{tabular}{|c|c|c|c|c|c|c|}
\hline \multirow{2}{*}{ 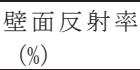 } & \multicolumn{3}{|c|}{ 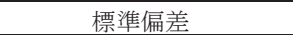 } & \multicolumn{3}{|c|}{ 変動係数（\%) } \\
\hline & 拡散 & 広照 & 中照 & 拡散 & 広照 & 中照 \\
\hline 30 & 6.7 & 2.9 & 5.0 & 3.4 & 2.8 & 14.0 \\
\hline 50 & 7.4 & 2.5 & 4.6 & 4.9 & 3.0 & 15.0 \\
\hline 70 & 64 & 82 & 41 & 58 & 36 & 160 \\
\hline
\end{tabular}

\section{4.2 暫定補正式の導出}

2. $4^{2}$ と $H^{2}$ の差と補正光束 $C F(H)$ はほぼ比例関係にあることから、 式(8)を参照し、暫定補正式を以下の式(9)とした。 $H$ を変数とする 2 次式であるが、 $H^{2}$ の変数項と定数項のみから成る簡便な式となった。 各配光器具において、壁面反射率が等しい場合は近似式の傾きが一定 と仮定しているため、式(9)における定数 $C$ は畳数によって変化せず、 更に簡便となっている。

$$
U F(H)=U F(2.4)-C\left(2.4^{2}-H^{2}\right) \quad \cdots(9)
$$$$
C: \text { 定数 }
$$

\section{4.3 補正による誤差を最小化する定数 $C$ の值の検討}

式(9)において定数 $C$ を畳数によって変化しない定数とした場合に、 暫定補正式を用いて算出した単位光束と照度計算ソフトにて算出した 単位光束との誤差が最小となる定数 $C$ の值を検討した。その際、暫 定補正式を用いて算出した単位光束の照度計算ソフトにて算出した単 位光束に対する比 $(=R)$ を算出し、誤差を確認した。

表 6 における近似式の傾きの各平均值付近の值を当てはめて、誤差 を最小化する定数 $C$ の值を求めた結果、各条件で $R$ が $0.9 \sim 1.1$ の間 にあり、誤差が $\pm 10 \%$ 以内に収まる定数 $C$ の值を見出した（表 8 ）。 $\pm 10 \%$ 以内に収まる定数 $C$ の值が複数ある場合は、照明設計におい ては明るくなる方の誤差が安全側であるため、マイナスの誤差が小さ くなる数值を選択するとともに、誤差の上下幅が小さくなる数值を選 択した。但しマイナスの誤差が 0 である場合は、実際の光束值が少し でも補正值を下回ると必ず誤差が生じることになるため除いている。 また、上下の誤差がいずれも等しい場合は、設計者の計算時の利便性 から切りのよい数值を選択している。

各条件における $R$ を示したものが図 8 である。但し、照明器具高
さ $2.4 \mathrm{~m}$ の場合は $R=1$ になることが自明であるので、データから省 いている。誤差が最大となる可能性の高い中照配光、壁面反射率 $70 \%$ の $R$ を表 9 に示した。これらより、 $R$ が $0.9 \sim 1.1$ の間にあることが 分かる。

表 8 定数 $C$ の検討値

\begin{tabular}{|c|c|c|c|c|c|c|c|c|c|}
\hline \multirow{3}{*}{$\begin{array}{l}\text { 壁 面 } \\
\text { 反 射 } \\
\text { 率 (\%) }\end{array}$} & \multicolumn{3}{|c|}{ 拡散 } & \multicolumn{3}{|c|}{ 広照 } & \multicolumn{3}{|c|}{ 中照 } \\
\hline & \multirow{2}{*}{ 定数 $C$} & \multicolumn{2}{|c|}{ 最大誤差 $(\%)$} & \multirow{2}{*}{ 定数 $C$} & \multicolumn{2}{|c|}{ 最大誤差 $(\%)$} & \multirow{2}{*}{ 定数 $C$} & \multicolumn{2}{|c|}{ 最大誤差 $(\%)$} \\
\hline & & + & - & & + & - & & + & - \\
\hline \multirow{3}{*}{30} & 183 & 9 & 0 & 108 & 13 & 6 & 39 & 16 & 8 \\
\hline & 184 & 8 & 1 & 109 & 10 & 8 & 40 & 10 & 9 \\
\hline & 185 & 7 & 2 & 110 & 7 & 10 & 41 & 5 & 11 \\
\hline \multirow{3}{*}{50} & 139 & 9 & 2 & 87 & 12 & 8 & 34 & 12 & 8 \\
\hline & 140 & 8 & 2 & 88 & 8 & 10 & 34.5 & 9 & 9 \\
\hline & 141 & 8 & 3 & 89 & 5 & 12 & 35 & 7 & 10 \\
\hline \multirow{3}{*}{70} & 99 & 8 & 1 & 66 & 12 & 7 & 28 & 12 & 9 \\
\hline & 100 & 8 & 1 & 67 & 9 & 9 & 28.5 & 9 & 10 \\
\hline & 101 & 7 & 2 & 68 & 5 & 11 & 29 & 7 & 11 \\
\hline
\end{tabular}

表注 : 斜字老採用

[拡散配光］
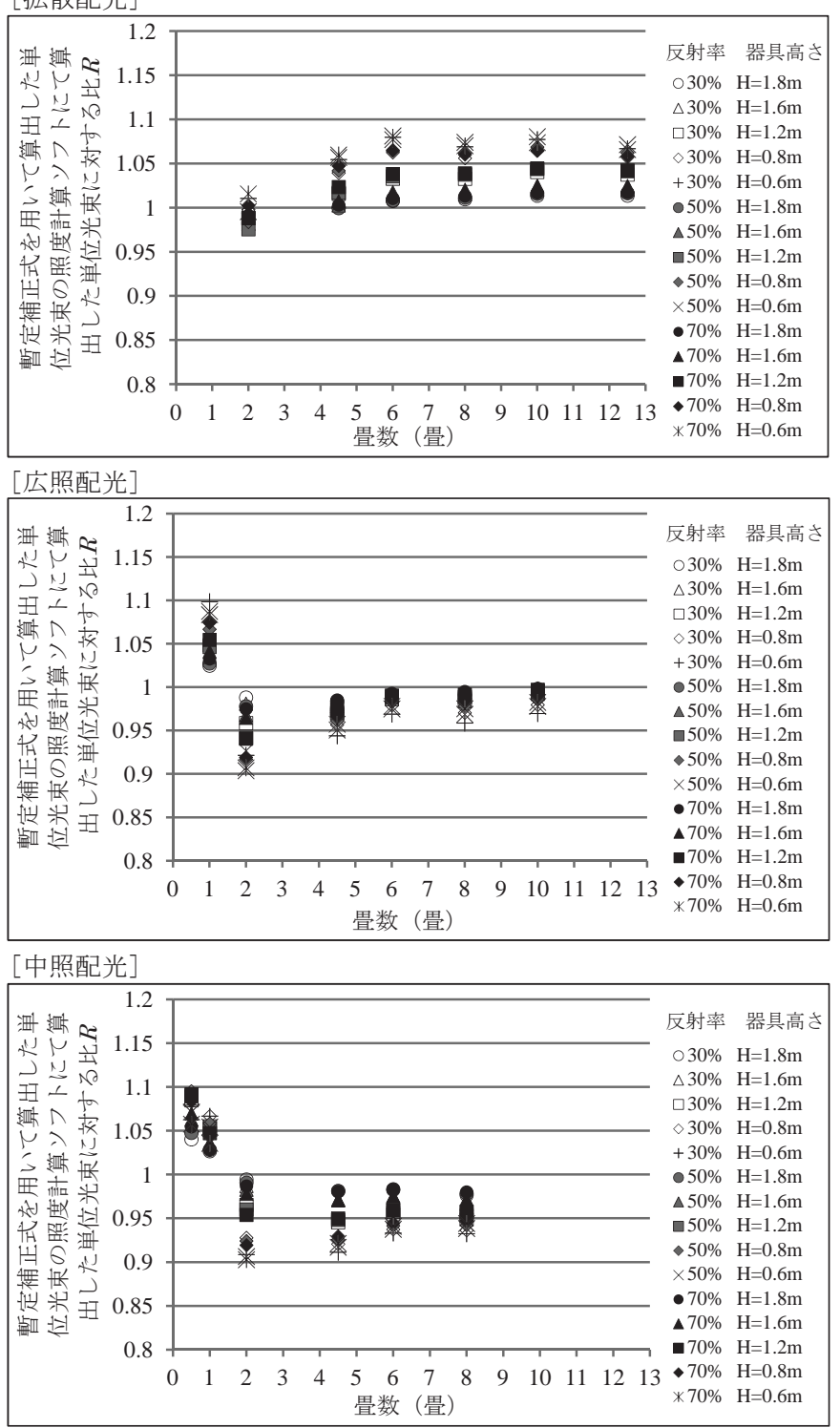

図 8 暫定補正式を用いて算出した単位光束の照度計算ソフトにて算 出した単位光束に対する比 $R(H=2.4 \mathrm{~m}$ を除く $)$ 
表 9 表 8 中の定数 Cを用いて補正した単位光束値 $U F(H)$ および暫定 補正式を用いて算出した単位光束の照度計算ソフトにて算出した単位 光束に対する比 $R$ [中照配光、壁面反射率 $70 \%$ の場合］

[UF(H) $(\mathrm{lm})]$

\begin{tabular}{|r|r|r|r|r|r|r|}
\hline 器具高 & \multicolumn{7}{|c|}{ 畳数(瞢) } \\
\cline { 2 - 7 } さ $(\mathrm{m})$ & 0.5 & 1 & 2 & 4.5 & 6 & 8 \\
\hline 2.4 & 229 & 290 & 375 & 639 & 806 & 1015 \\
\hline 1.8 & 149 & 213 & 307 & 579 & 746 & 963 \\
\hline 1.6 & 129 & 192 & 290 & 564 & 733 & 951 \\
\hline 1.2 & 97 & 160 & 264 & 543 & 712 & 932 \\
\hline 0.8 & 77 & 138 & 249 & 531 & 699 & 917 \\
\hline 0.6 & 71 & 132 & 244 & 527 & 693 & 912 \\
\hline
\end{tabular}

\begin{tabular}{|c|c|c|c|c|c|c|}
\hline \multirow{2}{*}{$\begin{array}{c}\text { 器具高 } \\
\text { さ }(\mathrm{m}) \\
\end{array}$} & \multicolumn{6}{|c|}{ 畳数 (畳) } \\
\hline & 0.5 & 1 & 2 & 4.5 & 6 & 8 \\
\hline 2.4 & 1.00 & 1.00 & 1.00 & 1.00 & 1.00 & 1.00 \\
\hline 1.8 & 1.05 & 1.03 & 0.99 & 0.98 & 0.98 & 0.98 \\
\hline 1.6 & 1.07 & 1.04 & 0.98 & 0.97 & 0.98 & 0.97 \\
\hline 1.2 & $1.09^{\text {注) }}$ & 1.05 & 0.95 & 0.95 & 0.96 & 0.96 \\
\hline 0.8 & 1.08 & 1.04 & 0.92 & 0.93 & 0.94 & 0.95 \\
\hline 0.6 & 1.06 & 1.04 & $0.90^{\text {注) }}$ & 0.92 & 0.94 & 0.94 \\
\hline
\end{tabular}

表注 : 斜字は最大值および最小值

図 8 より、拡散配光は誤差がほぼプラスに偏っているのに対して、 広照配光と中照配光では誤差がプラスとマイナスに分かれている。こ れは、まず拡散配光はマイナスの誤差が小さくなる定数 $C$ の值を採 用しているため概ねプラスの誤差が生じる。それに対して広照配光と 中照配光ではプラスおよびマイナスの誤差が生じる定数 $C$ の值を採 用しており、その值が 1 畳の場合の近似式の傾きと 2 畳の場合の近似 式の傾きの間にあるため、1 畳以下の場合はプラスの誤差が生じ、 2 畳以上の場合はマイナスの誤差が生じるためである。

\subsection{4 照明器具高さによる補正式}

全条件において、暫定補正式を用いて算出した単位光束の照度計算 ソフトにて算出した単位光束に対する比 $R$ が $0.9 \sim 1.1$ の間にあり、 誤差が士 $10 \%$ 以内に収まったため、照明器具高さ $0.6 \sim 2.4 \mathrm{~m}$ におけ る単位光束の照明器具高さによる補正式は式(9)にて問題ないことが 確認できた。但し、拡散配光器具と比較して広照配光器具と中照配光 器具はマイナスの誤差の幅が 2 倍程度ある。定数 $C$ は、配光の種類 と壁面反射率ごとに異なり、最終的に表 10 に示寸 9 通りの值を取る。

$U F(H)=U F(2.4)-C\left(2.4^{2}-H^{2}\right) \quad \cdots(9)$

表 10 定数 $C$ の值

\begin{tabular}{|l|r|r|r|r|}
\hline \multicolumn{2}{|c|}{} & 拡散配光器具 & 広照配光器具 & 中照配光器具 \\
\hline \multirow{2}{*}{$\begin{array}{l}\text { 壁面反 } \\
\text { 射率 }\end{array}$} & 30 & 184 & 109 & 40 \\
\cline { 2 - 5 }$(\%)$ & 50 & 140 & 88 & 34.5 \\
\cline { 2 - 5 } & 70 & 100 & 67 & 28.5 \\
\hline
\end{tabular}

この補正式の適用範囲は、天井高さを $2.4 \mathrm{~m}$ 、天井面反射率を $70 \%$ 、 壁面反射率を $70 \%$ 、50\%、30\%のいずれか、床面反射率を $10 \%$ とし た室内において、部屋あるいは明視照明ゾーンの床面積を拡散配光時 は $2 \sim 12.5$ 畳、広照配光時は $1 \sim 10$ 畳、中照配光時は $0.5 \sim 8$ 畳とし、 直接照明形で、拡散、広照、中照のいずれかの配光の照明器具を天井 中央の平面位置に一灯設置する場合に限る。

また、この補正式は誤差を $\pm 10 \%$ 以んとしている。通常、人間の感 覚量は刺激量の対数に比例し ${ }^{9)}$ 、明るさにおいても同様である。また 人間が明るさの違いを認識するには、約 1.5 倍の照度比が必要と考え られており、この考え方を用いて、JIS 照明基準総則 ${ }^{7)}$ では照度の基
準值を概ね 1.5 倍ずつ増加させている。このことから、住宅で必要な 照度を考える場合、基準值の $50 \%$ （基準值/1.5〜基準值 $\times 1.5$ の間） を許容範囲として問題ないと考えられる。今回の研究では基準值の士 10\%を誤差としており、十分に安全側の許容範囲と考えられる。

\section{4. 照明器具高さによる補正式を用いた設計の試行}

単位光束法の設計手順に従いながら、3.4.4 項で示した照明器具高 さによる補正式を用いた場合の実際の部屋を想定した設計の試行を行 い、どのような算出結果となるかの例を示す。

\section{1 室内全体の最大光束および最大消費電力の算出}

想定した部屋は、天井高さ $2.4 \mathrm{~m}$ で広さが 8 畳、内装反射率が天井 $70 \%$ ，壁 70\%，床 10\%の個室である（図 9）。設置する照明器具は ペンダントライトを想定していることから、照明器具設置高さ（照明 器具の下面の高さ）は $1.4 \mathrm{~m}$ とし、被照面は主にローテーブル付近を 想定している 2 畳の明視照明ゾーン(ゾーン 1 )の床面とした。ローテー ブルは床面より高くなるが、住まい手にとって明るくなる方の安全側 であるので、高さは無視している。

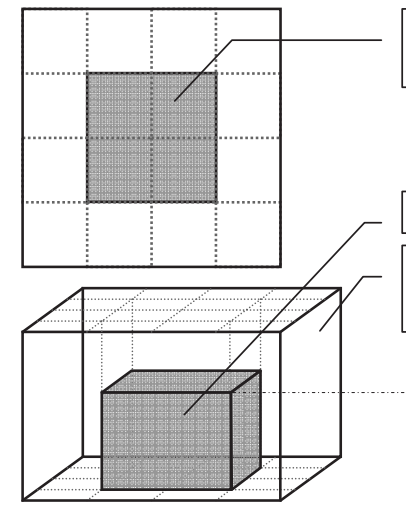

$$
\begin{array}{|l|}
\hline \text { ゾーン } 1: 2 \text { 畳 } \\
\text { ローテーブル付近 }
\end{array}
$$

ゾーン1の光束 (明視照明用光束) ゾーン1以外の光束 (雰囲気照明 用光束）

照明器具設置高さ $\mathrm{H}=1.4 \mathrm{~m}$

面積 (畳数) : 8 畳、間口: $3.64 \mathrm{~m} \times$ 奥行: $3.64 \mathrm{~m}$ 、天井高さ: $2.4 \mathrm{~m}$ 、 内装反射率: 天井 $70 \%$ ，壁 $70 \%$, 床 $10 \%$

\section{図 9 設計試行例の建築条件}

まず、この室内全体の最大光束および最大消費電力を算出する。拡 散配光器具の単位光束表（表 1 ）から、この条件における単位光束は $1700(\mathrm{Im})$ となる。室内全体の設計照度を $100(\mathrm{Ix})$ とすると、室内全体 の最大光束 $F_{\max }$ および最大消費電力 $W_{\max }$ は以下のように算出できる。

$$
\begin{aligned}
& F_{\max }=1700 \times(100 / 50)=3400(\mathrm{Im}) \\
& W_{\max }=3400 / 55 \fallingdotseq 61.8(\mathrm{~W})
\end{aligned}
$$

ここで最大消費電力 $W_{\max }$ を最大光束 $F_{\max }$ より求める際に用いる照 明器具の固有エネルギー消費効率は、単位光束法の設計手順に示すよ うに標準の $55(\mathrm{~lm} / \mathrm{W})$ 注5) を用いている。

\section{2 明視照明ゾーンの部分光束および部分消費電力の算出}

ゾーン1を主たる生活空間と想定し、設計照度を 200 (Ix) と設定する。 この $200($ IX) を拡散配光のペンダントライトが賄うとすると、拡散配 光器具の単位光束表（表 1 ） から単位光束は 1350 (Im) となる。この 時、ゾーン 1 は部屋の中央付近に位置しており、壁面がない状態であ ることから、壁面反射率が最も低い值（=30\%）を採用する注 ${ }^{9 ｝ \text { 。 }$

ここでペンダントライトの高さは $1.4 \mathrm{~m}$ であるので、照明器具高さ による補正を行う。式(9)に $U F(2.4)=1350(\mathrm{Im})$ と $H=1.4 \mathrm{~m}$ および 表 11 より抽出した $C=184$ を代入すると、 $U F(1.4) \fallingdotseq 651(\mathrm{Im})$ となる。 $U F(1.4)=1350-184 \times\left(2.4^{2}-1.4^{2}\right) \doteqdot 651(\mathrm{Im})$ 
これよりゾーン 1 における明視照明用の部分光束 $F_{\text {task }}$ および部分消 費電力 $W_{\text {task }}$ は以下のように算出できる。

$F_{\text {task }}=651 \times(200 / 50)=2604(\mathrm{Im})$

$W_{\text {task }}=2604 / 55 \doteqdot 47.3(\mathrm{~W})$

但し、照明器具高さの補正は下半球光束 ${ }^{8)}$ のみを持つ天井照明が前 提条件になっているため、採用するペンダントライトは下半球光束が 主体である直接照明形の配光を用い、部分光束 $F_{\text {task }}$ は採用する照明器 具の下半球光束のみを対象とする。ペンダントライトにおいては、直 接照明形においても少しの上半球光束 ${ }^{8)}$ を持つ場合があるが、これは 室内全体の最大光束 $F_{\max }$ には含めるが、明視照明用の部分光束 $F_{\text {task }}$ には含めない。

\section{3 雾囲気照明ゾーンの部分光束および部分消費電力の算出}

さらに、ゾーン 1 以外のゾーンを雾囲気照明ゾーンとし、そのゾー ンにおける部分光束および部分消費電力を算出する。

4. 2 節の結果より、雰囲気照明用の部分光束 $F_{\text {ambient }}$ および部分消 費電力 $W_{\text {ambient }}$ は以下のように算出される。

$F_{\text {ambient }}=F_{\text {max }}-F_{\text {task }}=3400-2604=796(\mathrm{Im})$

$W_{\text {ambient }}=W_{\max }-W_{\text {task }}=61.8-47.3=14.5(\mathrm{~W})$

これより、雰囲気照明器具は合計で $796(\mathrm{Im})$ および 14.5 (W)まで 使用可能となる。ペンダントライトが上半球光束を持つ場合は、その 光束およびその光束分の消費電力も含める。但し、最終的には室内全 体で用いる消費電力の合計が最大消費電力 $W_{\text {max }}$ 以下であれば問題な いため、ゾーンごとの消費電力の検討は目安とする。

\section{4 光束と消費電力の配分の検討および照明器具の選定}

明視照明用に下半球光束主体の拡散配光のペンダントライトを 1 灯、雰囲気照明用にフロアスタンドを 1 灯採用すると想定した場合の 各照明器具の光束および消費電力の配分例は表 11 の通りとなる。最 後に各照明器具に配分された光束および消費電力を参照して、照明メ ーカーのカタログ等から採用する照明器具を選定する。

表 11 ペンダントライトを用いる場合の光束と消費電力の配分例

\begin{tabular}{|c|c|c|c|c|c|c|c|}
\hline $\begin{array}{l}\text { 照明 } \\
\text { の } \\
\text { 種類 }\end{array}$ & 照明器具 & $\begin{array}{l}\text { 配光 } \\
\text { の型 }\end{array}$ & 数 & $\begin{array}{l}\begin{array}{l}\text { 光束 } \\
\text { 灯 } \\
(\mathrm{Im})\end{array} \\
\end{array}$ & $\begin{array}{l}\text { 消費電 } \\
\text { 力 } \\
(\mathrm{W})\end{array}$ & $\begin{array}{l}\text { 光束 } \times \\
\text { 灯数 } \\
(\mathrm{Im})\end{array}$ & $\begin{array}{l}\text { 消費電 } \\
\text { 数 } \times \text { 灯 } \\
\text { 数 }(\mathrm{W})\end{array}$ \\
\hline 琞視 & $\begin{array}{l}\text { ペンダントラ } \\
\text { イト (下半球 } \\
\text { 光束分) }\end{array}$ & 拡散 & 1 & 2604 & 47.3 & 2604 & 47.3 \\
\hline \multirow[t]{2}{*}{$\begin{array}{l}\text { 雰囲 } \\
\text { 気 } \\
\text { 照明 }\end{array}$} & $\begin{array}{l}\text { ペンダントラ } \\
\text { イト (上半球 } \\
\text { 光束分) }\end{array}$ & - & 1 & 260 & $4.7^{\text {洋2) }}$ & 260 & 4.7 \\
\hline & $\begin{array}{l}\text { フロア } \\
\text { スタンド }\end{array}$ & - & 1 & $536^{\text {i\#3) }}$ & $9.7^{\text {洋2) }}$ & 536 & 9.7 \\
\hline & & & & & 合計 & 3400 & 61.7 \\
\hline
\end{tabular}

表注 $1:$ 例として下半球光束の $10 \%$ としている。

表注 2 : 標準の固有エネルギー消費効率 $(55(\mathrm{~lm} / \mathrm{W}))$ で除して算出している。

表注 3 : 雾囲気照明器具の光束の合計が $796(\mathrm{~lm})$ となるように算出している。

\section{5．照度計算ソフトを用いた光環境および消費電力の確認}

単位光束法の照明器具高さによる補正を用いて照明器具を選定した 場合の光環境および消費電力の実用性を、4 章の設計試行例の条件に 基づき、照度計算ソフトを使用して室内の照度分布を検討する専門的 な照明設計法（以下「詳細法」とする）を用いて確認した。

\section{1 詳細法による照明設計}

設計試行例の結果をもとに、実在の照明器具を選定して適切に配置 し（図 10）、照度分布図を作成した。正確な照明器具の設置位置お よび配光データを用いて、照度計算ソフト注 10) を活用し、直接光によ
る照度值と相互反射計算を行って算出した間接光による照度值を合計 して床面における逐点の照度值を算出している。図 11 がその際に作 成した照度分布図であり、表 12 が使用器具の一覧表、表 13 が算出し た床面平均照度值の一覧表である。

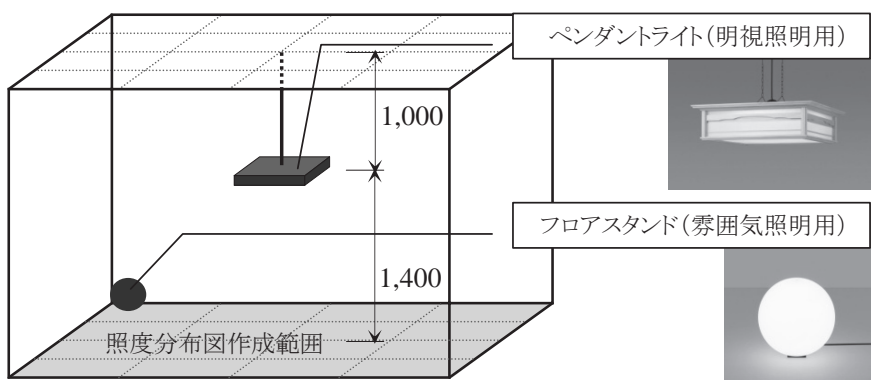

図 10 ペンダントライトを用いる場合の照明器具配置

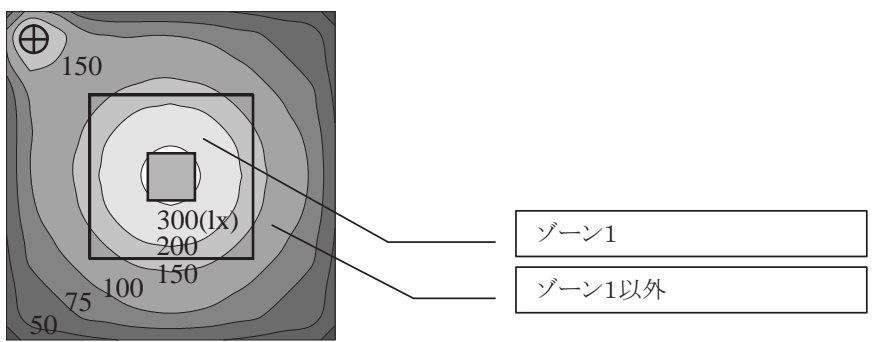

図 11 ペンダントライトを用いる場合の床面照度分布図

表 12 ペンダントライトを用いる場合の使用器具

\begin{tabular}{|c|c|c|c|c|c|c|}
\hline ゾーン & 照明器具 & $\begin{array}{l}\text { 配光の } \\
\text { 型 }\end{array}$ & ランプ & $\begin{array}{l}\text { 光束 } \\
(\operatorname{lm})\end{array}$ & \begin{tabular}{|c} 
消費電力 \\
$(\mathrm{W})$
\end{tabular} & \\
\hline $\begin{array}{l}\text { ゾーン 1 } \\
\text { (明視照明) }\end{array}$ & $\begin{array}{l}\text { ペンダントライト } \\
\text { (下半球光束分) }\end{array}$ & 拡散 & $\begin{array}{l}\text { 内藏 } \\
\text { LED }\end{array}$ & $2604^{\text {注 1) }}$ & $37.4^{\text {注 } 2)}$ & \\
\hline \multirow[t]{2}{*}{$\begin{array}{l}\text { ゾーン } 1 \text { 以外 } \\
\text { (雰囲気照明) }\end{array}$} & $\begin{array}{l}\text { ペンダントライト } \\
\text { (上半球光束分) }\end{array}$ & - & - & $389^{\text {注 } 3)}$ & $5.6_{\text {注 2) }}$ & \\
\hline & フロアスタンド & 全周注 4) & $\begin{array}{l}\text { 電球形 } \\
\text { LED } \\
\text { ランプ }\end{array}$ & 380 & 6.2 & \\
\hline
\end{tabular}

表注 1 : 調光を想定し、単位光束法で算出した光束を用いている。

表注 2 : 光束を採用した照明器具の固有エネルギー消費効率 $(69.6(\mathrm{~lm} / \mathrm{W}))$ で除 して算出している。

表注 3 : 照明器具の上半球光束にン゙ーン 1 の下半球光束と同じ調光率を乗じて 算出している。

表注 4 : 照明器具の全周に光が出る配光。

表 13 ペンダントライトを用いる場合の床面平均照度值

\begin{tabular}{|l|r|r|r|r|}
\hline \multicolumn{1}{|c|}{ ゾーン } & \multicolumn{1}{|c|}{$\begin{array}{c}\text { 平均照度 } \\
(\mathrm{lx})\end{array}$} & $\begin{array}{c}\text { 均斎度 } \\
\text { (最小/平均) }\end{array}$ & \multicolumn{1}{c|}{$\begin{array}{c}\text { 光束合計 } \\
(\mathrm{lm})\end{array}$} & $\begin{array}{l}\text { 消費電力合計 } \\
(\mathrm{W})\end{array}$ \\
\hline ゾーン 1 & 223 & 0.64 & 2604 & 37.4 \\
\hline ゾーン 1 以外 & - & - & 769 & 11.8 \\
\hline 室内全体 & 129 & 0.17 & 3373 & 49.2 \\
\hline
\end{tabular}

\section{2 光環境および消費電力の確認}

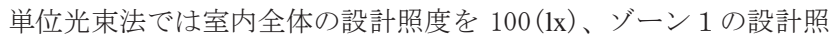
度を 200 (Ix) と設定しているが、表 13 の結果より、室内全体において は床面平均照度が $100(\mathrm{Ix})$ 以上、ゾーン 1 においては $200(\mathrm{Ix})$ 以上得 られており問題ない。また、照度分布図から室内全体において概ね 50 (IX) 以上となっており、JIS 照明基準総則 ${ }^{7)}$ における全般の床面平 均照度が 50 (IX)であることから、暗い部分がほとんどないことが確認 できた。消費電力は最大消費電力以下であり、標準的な消費電力より 小さいため問題ない。 


\section{6. 考察}

\section{1 照明器具高さによる補正の実用性}

単位光束法の照明器具高さによる補正の実用性の検討のため、4 章 および 5 章にて設計例の試行と詳細法による検証を行った。その結果、 光環境および消費電力の両面で問題はなく、簡易設計法としての単位 光束法における照明器具高さによる補正の実用性が高い可能性が示さ れた。

\section{2 照明器具高さによる補正の留意点}

本研究にて導出した照明器具高さによる補正式の適用範囲は 3.4.4 項に示した通りであるが、室内各面の反射率が適用範囲より大きい条 件においては、床面平均照度が $+10 \%$ を超える誤差になる可能性はあ るが、照明設計上安全側として、本補正式の使用は可能と考えられる。

また、照明器具高さによる補正を含む単位光束法の使用に際しては、 設計時に居室における生活行為の種類を明確にしておく必要がある、 雾囲気照明を優先する設計に適していない、単位光束法を用いても不 適切な照明器具の選択や配置を行った場合に光環境の問題が生じるな ど、前報 ${ }^{3)}$ からの留意点も引き継いでいる。

\section{7. まとめ}

\section{1 結論}

単位光束法は住宅建築設計者が簡易に照明設計を行えることを目的 とした照明設計法であるが、従来は明視照明ゾーンにおいて、シーリ ングライトなどの天井照明のみが適用対象であった。

本研究において、照明器具高さが $2.4 \mathrm{~m}$ の場合の単位光束と照明器 具高さが $2.4 \mathrm{~m}$ より小さい場合の単位光束の差に着目し、照明器具高 さ $0.6 \sim 2.4 \mathrm{~m}$ における単位光束の照明器具高さによる補正式を導出 した。これにより、明視照明ゾーンにおいて、ペンダントライトなど の照明器具高さが天井高さより小さい照明器具にも対応できる単位光 束法となった。

この補正式は、設計照度としての床面平均照度における誤差を土 $10 \%$ 以内とすると、天井高さを $2.4 \mathrm{~m}$ 、天井面反射率を $70 \%$ 、壁面反 射率を $70 \% 、 50 \% 、 30 \%$ のずれか、床面反射率を $10 \%$ とした部屋 において、部屋あるいは明視照明ゾーンの床面積を拡散配光時は 2〜 12.5 畳、広照配光時は $1 \sim 10$ 畳、中照配光時は $0.5 \sim 8$ 冨とし、直接 照明形で、拡散、広照、中照のいずれかの配光の照明器具を天井中央 の平面位置に一灯設置する場合が適用範囲と定まる。但し、室内各面 の反射率が適用範囲より大きい条件においては、床面平均照度が+ 10\%を超える誤差になる可能性はあるが、照明設計上安全側として、 本補正式の使用は可能と考えられる。

また、設計試行例による検証により、補正式の実用性が高い可能性 が示された。

\section{2 今後の課題}

設計者の利便性を高めるために、本研究で示した適用範囲外の条件 において、照明器具高さによる補正の適用の可否を検討し、適用範囲 の拡大を図る必要がある。

\section{謝辞}

本研究は京都大学の原田和典教授の御指導・御助言を頂きました。 ここに記して感謝の意を表します。
注

注 1) 器具光束は照明器具から全ての方向に放出される光の量のこと。照明器具 の光束にはランプ光束と器具光束があるが、単位光束の算出には器具光束を 用いる。

注 2) 新たに作成する際には共通のデータベースに一元化し、学会などの公的機 関や照明メーカーなど多くの作成者が参加することが望ましい。

注 3) 単位光束法では、室内を明るい部分と暗い部分に分ける手順があり、明る さのゾーニングと呼ぶが、その分けられた部分をゾーンと呼んでいる。

注 4) 固有エネルギー消費効率 $(I \mathrm{~m} / \mathrm{W})=$ 器具光束 $(\mathrm{Im}) /$ 消費電力 $(W)$

注 5) 今後増加すると考えられる電球色のランプ一体型 LED ダウンライト（単 位光束表における中照配光器具）の固有エネルギー消費効率に近い值を標準 值として採用している。この值は、照明器具の効率向上や照明プランのスタ イルの変化に合わせて、定期的に見直すことで将来の対応が可能となる。

注 6) 照明計算アルゴリズムに光線追跡法を用いて照明シミュレーションを行う フリーソフトウェア。

注 7) Radiance の解説書 ${ }^{10)}$ において人工照明使用時に適度に正確な（reasonably accurate) レンダリングに推奨されているパラメータ (-ab 2, -aa 0.15, -ar $128,-\operatorname{ad} 512,-\operatorname{as} 256)$ よりも間接光の反射回数を 1 回多くして (-ab 3)、計 算精度を高めている。

注 8) 室内の間接照度は、その室内各面からの第一回反射光束、室内の表面積お よび平均反射率をパラメータとする算出式で近似できる ${ }^{11)}$ 。本研究で想定す る直接照明形配光の照明器具は床面への直接入射光およびその第一回反射光 束が大きいため、その床面からの第一回反射光束、室内の表面積および平均 反射率にて床面の間接照度を近似的に算出できるとみなせる。本研究におい ては、照明器具の高さを変えても、単位光束算出時の床面の基準照度および 反射率は固定であるため、床面からの第一回反射光束は概ね一定であり、室 内の表面積や室内各面の反射率も一定であることから、床面の間接照度は概 ね一定となる。

注 9) 住宅のような小規模な空間では、ゾーン外の照明器具から到達する光束や 室内壁面からの反射光束による照度増加分が期待できるため、ゾーン四周に 壁面がない状態においても壁面反射率 30\%の值を採用している ${ }^{3)}$

注 10) 東芝照明設計システム TX：CIE (国際照明委員会)の推奨法である CIE 法を改良した CIET 法に基づく 6 面間相互反射連立方程式を解くアルゴリズ ムを採用した照度計算を行うソフトウェア ${ }^{12)}$ 。単位光束法算出時に用いた Radiance と異なるソフトウェアであるが、CIET 法は照明計算理論として確 立されており ${ }^{13)}$ 、前報までの設計試行例において本ソフトウェアを用いてい ることから、本研究の設計試行例においても照度分布図を同条件で作成する ために用いている。

\section{参考文献}

1）三木保弘，戸倉三和子，淺田秀男，松下進 : 小型高効率ランプを用いた多灯 分散照明の提案とリビング・ダイニングにおける被験者評価及び省エネルギ 一性評価 住宅における多灯分散照明による光環境の質と省エネルギー性の 両立に関する研究 その 1, 日本建築学会環境系論文集，603 号，pp. 9-16, 2006. 5

2) JIEG-009 住宅照明設計技術指針，照明学会，2007

3）松下進，三木保弘：単位光束法の提案 住宅における多灯分散照明方式に適 した簡易照明設計法に関する研究，日本建築学会環境系論文集，686 号， pp. 325-331，2013. 4

4）松下進，三木保弘，上谷芳昭: 住宅におけるランプ分離型および一体型照明 器具に対応する器具光束を用いた単位光束法の提案, 日本建築学会環境系論 文集， 719 号，pp. 57-64，2016.1

5）準寒冷地版自立循環型住宅への設計ガイドライン，p. 306, 建築環境・省エ ネルギー機構, 2012

6）照明学会編：照明ハンドブック, p. 147, 照明学会, 2003

7）日本工業標準調査会：JIS 照明基準総則（JIS Z9110-2010）

8) 照明学会編 : 照明ハンドブック, p. 70, 照明学会, 2003

9）照明学会編 : 照明ハンドブック, p. 260, 照明学会, 2003

10) Axel Jacobs, Radiance Tutorial, JALOXA, p. 32, 2012

11）松浦邦男，建築照明，共立出版，pp. 115-116, 1971

12）菊池壮一他，照明設計支援システム，照明学会全国大会講演論文集 30 , p. 144, 1997

13) 高橋貞夫他，室内照明における照度予測の電子計算化，照明学会誌 54(12), pp. 697-707, 1970.12 


\title{
CORRECTION OF FLUX-UNIT METHOD BY LUMINAIRE HEIGHT \\ AND THE APPLICABLE RANGE
}

\section{Susumu MATSUSHITA*, Yasuhiro MIKI** and Yoshiaki UETANI***}

\author{
* President, Susumu Matsushita Architecture \& Lighting Design Labo., M. Eng. \\ Grad. Student, Dept. of Architecture and Architectural Engineering, Kyoto University \\ ** Head, Building Environment Division, Housing Department, National Institute for Land and Infrastructure Management, MLIT, Dr. Eng. \\ *** Assoc. Prof., Dept. of Architecture and Architectural Engineering, Kyoto University, Dr. Eng.
}

"Flux-unit method" that we proposed previously is a simple lighting design method applicable to both non-integrated luminaires and integrated luminaires for residential architects. By using "Flux-unit method", the architects can design the brightness in the room depending on the chamber size and interior reflectance easily. They can calculate the amount of luminaire luminous flux of luminaires to obtain necessary floor average illuminance of whole or zone of the room manually. Further, they can calculate the amount of electric energy by converting luminaire luminous flux into wattage with luminaire efficacy rating.

Since this method in our previous studies assumes the use of luminaires on the ceiling, there is a precondition that luminaire height is constant. Although there is no problem when luminaire height is nearly equal to ceiling height, such as ceiling lights and down lights that are often used in residential lighting, this method cannot be used when luminaire height is less than ceiling height as pendant lights.

Therefore, the purpose of this study is to propose the correction formula of "Flux-unit method" by luminaire height in the case that luminaire height is less than ceiling height. First, we calculated "flux-unit" under the conditions of various luminaire height to organize the relationship between luminaire height and "flux-unit". Next, we focused on the difference between "flux-unit" of various luminaire height and the "flux-unit" of ceiling height $(2.4 \mathrm{~m})$, to consider the correction formula by luminaire height.

As a result, we got the correction formula of "flux-unit" that correct "flux-unit" of ceiling height $(2.4 \mathrm{~m})$ by luminaire height. The correction formula is as follows:

$U F(H)=U F(2.4)-C\left(2.4^{2}-H^{2}\right)$

$U F(H)$ : "flux-unit" of luminaire height as $H(\mathrm{~lm}) 、 H$ : luminaire height $(\mathrm{m})$

$U F(2.4)$ : "flux-unit" of luminaire height as $2.4(1 \mathrm{~m}) 、 C$ : constant

Furthermore, procedures of this new "Flux-unit method" were shown and one trial design with this method was also executed to verify brightness distribution by using a illuminance image. The result of verifying the usefulness of this method shows sufficient potential to be practical.

Consequently, it was shown that "Flux-unit method" is applicable to luminaires of various height under the limited applicable range used in this study.

(2016 年 7 月 19 日原稿受理, 2017 年 6 月 7 日採用決定) 